・论坛・ 中国国家公园试点专题

\title{
南山国家公园体制试点建设经验
}

\author{
曾晴, 雷光春@*
}

北京林业大学生态与自然保护学院, 北京 100083

曾晴, 雷光春 (2021) 南山国家公园体制试点建设经验. 生物多样性, 29, 319-320. doi: 10.17520/biods.2021042.

Zeng Q, Lei GC (2021) The practice of Nanshan National Park system pilot. Biodiversity Science, 29, 319-320. doi: 10.17520/biods.2021042.

\section{The practice of Nanshan National Park system pilot}

Qing Zeng ${ }^{\circledR}$, Guangchun Lei ${ }^{\circledR *}$

School of Ecology and Nature Conservation, Beijing Forestry University, Beijing 100083

南山国家公园体制试点位于南岭山脉与雪峰 山脉交汇地带, 是我国东部湿润半湿润生态大区南 亚热带与中亚热带交汇区，同时是中国第二级阶梯 云贵高原向第三级阶梯江南丘陵的过渡带, 也是我 国“两屏三带”生态安全战略中“南方丘陵山地带”的 典型代表, 生物多样性极为丰富。植物区系上属于 华中、华南、华东、西南四大区系交叉“十字路口”, 境内有南岭地区保存最完整的中亚热带低海拔常 绿阔叶林, “东南亚第一近城绿色长廊”两江峡谷, 以及我国中南地区规模最大的中山泥炭藓沼泽湿 地。该区域是长江流域沅江水系、资江水系、湘江 水系和珠江流域西江水系的源头和重要水源涵养 地。因为生态系统代表性、原真性和完整性强, 自 然资源价值国家代表性突出, 保护价值和生物学意 义巨大, 南山国家公园体制试点于2016年设立, 有 效地探索了在我国南方集体林区国家公园的创建 之路, 为经济欠发达地区、少数民族地区和革命老 区推进以国家公园为主体的自然保护地体系建设, 创造了可复制、可推广的南山经验和南山样板。

1 南方集体林区发展与生态系统保护互助 模式

试点区位于湖南省邵阳市城步苗族自治县境 内, 总面积63,594 ha, 林地面积56,927.59 ha, 包括
集体林地36,240 ha。为实现生态系统的统一管理, 试点区推进了集体林 “三权分置”改革, 致力破解我 国南方集体林地占比大、管理难的问题，包括如下 举措：(1)对集体土地实施了公益林区划调整，将 3,936.2 ha的商品林全部一次性增补, 纳入公益林 和天保林管理范畴。(2)实施集体林经营权租赁流转, 在不改变集体林地所有权和林地用途的前提下, 按 照自愿原则, 采取20元/亩/年的租赁方式, 将经营 权统一流转给南山国家公园管理局, 共流转 3,058 户15,226.7 ha (占集体林地总面积的42\%)。(3)对未 实施经营权流转的集体林地(占集体林地总面积的 58\%), 以签订合作保护协议的方式实行统一管理。 此外, 提高集体公益林补偿标准。将实施经营权流 转统一管理的集体公益林和集体天保林补偿标准 分别由每年的15.5元/亩、13.5元/亩提高至30元/亩, 按国家有关政策规定提高标准, 超过30元/亩的部 分仍归集体或个人所有。(4)设置了生态公益岗位, 吸纳贫困户护林员、环卫员等公益岗位人员496人, 均为当地居民。此外, 在实行集体林地统一管理的 前提下, 适度允许并引导一般控制区内原居民发展 林下经济等生态型替代产业, 构建生态经济体系, 如林蜂养殖、青钱柳(Cyclocarya paliurus)、金银花 (Lonicera japonica)、天麻(Gastrodia elata)和七叶一 枝花(Paris polyphylla)种植等。试点区所在地城步县 
是国务院实施扶贫开发战略的发源地, 也是国家扶 贫开发工作重点县、商务部定点扶贫县和湖南省 11 个深度贫困县之一。结合精准扶贫, 22 个贫困村全 部脱贫摘帽，试点区内居民人均可支配收入由 2017 年的6,310元上升至2019年的9,291元，提升了 47.2\%, 明显超过试点外同类地区居民收入水平。国家公园 试点充分发挥了生态效益，改善了民生，探索出了 我国南方集体林区社区发展与生态系统保护互助 共赢的新模式。

\section{2 创新管理运行机制}

试点区内涉及 4 个原有不同类别的国家级自然 保护地, 即南山风景名胜区、湖南两江峡谷森林公 园、湖南金童山自然保护区、湖南白云湖湿地公园, 存在保护地重叠、行政分割、管理破碎化等情况。 南山国家公园试点区将原 4 个自然保护地及其管理 机构承担的管理职责, 全面整合划入南山国家公园 管理局, 各保护地原管理机构作为南山管理局下属 事业单位予以保留, 机构规模维持不变。

试点区首创了国家公园行政权力清单集中授 权机制。依据《中华人民共和国行政许可法》 《中 华人民共和国行政处罚法》 《建立国家公园体制总 体方案》等规定，将省市县有关行政许可、行政执法、 行政处罚等197项行政管理权力授予南山管理局, 为 南山国家公园管理局依法行政提供了有力支撑。

资金使用机制方面，试点区建立了南山公园一 级账户统筹资金使用管理机制，充分发挥了资金集 中优势，极大提升了资金整合效益，确保了南山国 家公园保护、运行和管理需要。湖南省委、省政府 主动承担试点主体责任, 积极构建财政投入为主的 资金保障机制，并在中央财政投入基础上，多渠道 筹措试点资金。同时，社会支持力度也不断加大，已 接收社会捐赠420万元，实现试点前零记录的突破。

\section{3 南方低山丘陵生态系统保护路得}

试点区位于南方人口相对密集区、生态系统片 断化, 为推进自然资源的系统和整体保护, 维护生 态系统完整性和连通性, 试点区系统研究了范围调 整, 创造条件整合周边属同一生态地理单元的自然 保护地，论证并纳入了毗邻的黄桑、舜皇山等相邻 国家级自然保护区，囊括了同纬度地区保存最为完 好的常绿阔叶林生态系统(何汉杏和何秀春, 2003)。
此外, 分析了保护空缺, 充分吸纳生态红线, 通过 建立生态廊道将各片区串联，最大化实现生态系统 完整性。

试点区内 20 世纪70年代建设的南山牧场总面 积3,836.69 ha，人工牧草地达 $2,045.95$ ha。人工改良 草原对促进城步县少数民族地区经济发展和当地 群众脱贫致富作出了贡献，但产草量和草地面积在 逐年退化，目前尚有奶牛3,000余头。考虑其是连通 南山片区与黄桑片区的重要生态廊道及红色文化 的重要载体, 试点区将逐渐禁止放牧, 并对其进行 生态修复, 促进自然演替。

试点区积极探索了南方景观破碎化山地中具 有重要保护价值的原生残余斑块的保育修复，通过 扩大面积、建立生态廊道等方式推进生态系统原真 性、完整性保护。并加强监测调查, 发现维管束植 物新种 2 个(Wang et al, 2019)、脊椎动物新种 4 个, 新 记录维管束植物447种、脊椎动物68种。

南山国家公园体制试点区对于南方集体林区 生态、社会、经济重大而深远的影响，为探索我国 南方低山丘陵生态系统保护的新路径、探索南方少 数民族聚居地社区发展与生态系统保护互助共赢 的新模式、跨层级多部门协同管理的高效机制提供 了丰富的经验。

致谢: 感谢南山国家公园管理局的支持。本文核心 数据引自《南山国家公园体制试点自评报告》及《国 家公园体制试点评估验收综合报告》。

\section{ORCID}

曾晴 (D) https://orcid.org/0000-0002-7471-4941

雷光春 (D) https://orcid.org/0000-0001-9021-5758

\section{参考文献}

He HX, He XC (2003) A numerical and synthetic study of evergreen and broad-leaved tree species in Shunhuang Mountain of Hunan Province. I. Study of species significant value. Journal of Central South Forestry University, 23(2), 16-21. (in Chinese with English abstract) [何汉杏, 何秀春 (2003) 湖南舜皇山常绿阔叶林种类组成数量综合特征. I. 乔木物种重要值. 中南林学院学报, 23(2), 16-21.]

Wang L, Deng X, Liu Y, Wu Q, Liu Z (2019) A new species of the genus Megophrys (Amphibia: Anura: Megophryidae) from Hunan, China. Zootaxa, 4695, 301-330.

(责任编委: 徐卫华 责任编辑: 间文杰) 